\title{
ANALISIS IN SILICO PROTEIN CLOCK (CIRCADIAN LOCOMOTOR OUTPUT CYCLES KAPUT) PADA Patagioenas fasciata monilis
}

\author{
Suprianto $^{1}$, I Made Budiarsa ${ }^{1}$ \\ ${ }^{1}$ Program Studi Pendidikan Biologi Universitas Tadulako Jl. Soekarno-Hatta KM 9, Palu, \\ Indonesia
}

e-mail: supriantoupick28@gmail.com,budiarsa_imade@yahoo.com

\begin{abstract}
Abstrak
CLOCK merupakan protein penting yang berperan dalam adaptasi ekologi dan fisiologi organisme. Studi sebelumnya menjelaskan bahwa CLOCK memiliki pengaruh terhadap perubahan perilaku hewan. Penelitian ini bertujuan untuk menganalisis protein CLOCK pada burung Patagioenas fasciata monilis. Metode yang digunakan pada penelitian ini adalah metode homologi. Hasil struktur model berdasarkan assessment menunjukkan akurasi model yang mendekati struktur sebenarnya. Struktur model yang diperoleh memiliki berat 96200,04 Daltons, tiga daerah struktur beta-sheet, lima daerah struktur alphahelix, 1,47\% daerah outliers, dua residu C-Beta Deviations, nilai identity $94,43 \%, 34$ sudut buruk, nilai QMEAN -1,69 dan nilai GMQE 0,31.
\end{abstract}

Kata Kunci : CLOCK, Patagioenas fasciata monilis, in silico, homologi

\begin{abstract}
CLOCK is an important protein that plays a role in the ecological and physiological adaptation of organisms. Previous studies have shown that CLOCK has an effect on changes in animal behavior. This study aims to analyze the CLOCK protein in Patagioenas fasciata monilis. The method used in this research is the homology method. The results of the model structure based on the assessment show the accuracy of the model which is close to the actual structure. The model structure obtained has a weight of 96200.04 Daltons, three regions of the beta-sheet structure, five regions of the alpha-helix structure, $1.47 \%$ of the outliers area, two residues of C-Beta Deviations, $94.43 \%$ identity value, 34 bad angles, QMEAN value 1.69 and $G M Q E$ value 0.31 .
\end{abstract}

Keywords: CLOCK, Patagioenas fasciata monilis, in silico, homology

\section{PENDAHULUAN}

Proses fisiologi dan perilaku pada hewan dipengaruhi oleh aktivitas endogen yang disebut sirkadian clock (Johnsen, et al., 2007). Sirkadian Clock membentuk osilator inti yang melibatkan satu set "Gen Clock" (Panda, et al., 2002) seperti per1, per2, per3, cry1 dan cry2 (Takashi, 2017). Gen clock berperan sebagai regulator negatif dengan menghambat transkripsi melalui pengikatan E-box pada promotor per1 dan per2 (Okamura, 2003). Gen clock mengkodekan protein CLOCK yang terlibat dalam sirkadian clock (Gekakis, et al., 1998) CLOCK merupakan komponen yang sangat berperan penting dalam mekanisme sirkadian clock, bekerja sebagai aktivator transkripsi (Hardin, 2000). Protein CLOCK bersama BMAL1 membentuk kompleks bHLH-PAS yang mengatur ritme sirkadian Clock (Wang, et al., 2013).

Protein CLOCK menjadi daya tarik peneliti, karena memiliki fungsi penting dalam mempengaruhi adaptasi ekologi dan fisiologi hewan (Beale, et al., 2016). Beberapa penelitian CLOCK pada burung menunjukkan adanya perbedaan, seperti lima jenis burung dari kelompok Tachycineta memiliki panjang yang berbeda (Dor, et al., 2011). Perilaku harian burung sangat dipengaruhi oleh fungsi 
biologis CLOCK (Cassone \& Westneat 2012), seperti Patagioenas fasciata monilis mempunyai perilaku yang khas. Burung ini hanya akan meletakan satu atau dua telur didalam sarangnya (Hogan, 2008). Burung Patagioenas fasciata monilis sangat penting untuk dilestarikan, karena digunakan dalam upaya mengembalikan spesies yang punah (Nathaniel, 2014).

Penelitian ini bertujuan untuk menganalisis protein CLOCK pada burung Patagioenas fasciata monilis secara in silico, kebutuhan data molekuler saat ini sangat dibutuhkan dalam keperluan banyak hal seperti konservasi, sehingga studi kasus dalam penelitian ini akan sangat membantu dalam menyediakan informasi dasar ditingkat molekuler. In silico menjadi pilihan utama penelitian karena tidak membutuhkan dana yang cukup besar (Amelia, 2010), tetapi mampu menyediakan informasi akurat dalam mengolah sequence database nukleotida dan protein. Penelitian dengan analisis in silico akan memberikan informasi penting tentang struktur protein dalam menjelaskan karakter dan fungsi protein ditingkat molekuler.

\section{METODE}

Sequence protein CLOCK pada Patagioenas fasciata monilis dengan kode akses OPJ71137.1, diunduh dalam bentuk fasta dan diperoleh dari situs NCBI (National Center Biotechnology Information) dengan template 4f3I.1.B (PDB-ID) yang didapatkan dari hasil identifikasi template di Swiss Model. Penelitian ini menggunakan beberapa software yang mendukung proses penelitian diantaranya adalah NCBI (https://www.ncbi.nlm.nih.gov/) Protein Data Bank

(http://www.pdb.org/pdb/home/home.do, server), Program Swiss Model expacy (http://swissmodel.expasy.org/) dan Bioedit versi 7.2.5.

Tahap penelitian meliputi penentuan protein target menggunakan software $\mathrm{NCBI}$ dan PDB, menganalisis komposisi asam amino sequence protein target, identifikasi template serta prediksi struktur 3D protein target menggunakan Swiss Model dengan pendekatan homologi. Prediksi struktur 3D protein dengan pendekatan homologi menjadi pilihan utama dalam membangun struktur model (Arnold, et al., 2006) untuk mendeskripsikan karakter molekuler protein.

\section{HASIL DAN PEMBAHASAN}

\section{Penentuan sequence protein CLOCK pada Patagioenas fasciata monilis dan Identifikasi template}

Sequence protein CLOCK pada Patagioenas fasciata monilis diperoleh dari database NCBI. Pemilihan sequence protein ditentukan berdasarkan pemeriksaan kode akses protein. Protein dengan kode akses tertentu yang belum terdaftar didalam PDB bertujuan untuk menghindari similaritas penelitian sebelumnya (Suprianto, et al., 2020). Berdasarkan penelusuran sequence protein target menunjukkan bahwa protein CLOCK dengan kode akses OPJ71137.1 menjadi protein yang akan dikaji lebih lanjut mengenai komposisi asam amino dan struktur tiga dimensi proteinnya, dikarenakan protein tersebut belum terdaftar didalam database PDB. Template sangat diperlukan dalam memprediksi struktur tiga dimensi protein, tanpa template struktur protein tidak akan terbangun. Identifikasi template dilakukan menggunakan Swiss Model melalui search for template dengan memasukkan data sequence protein CLOCK yang memiliki kode akses OPJ71137.1 kedalam workspace di Swiss Model. Pemilihan template dengan identity diatas $50 \%$ menjadi pilihan utama dalam memprediksi struktur tiga dimensi protein dikarenakan jika identity antara target dengan template hanya berkisar $30-50 \%$, maka struktur yang diprediksi masih sangat jauh dari struktur sebenarnya.

$$
\text { Besarnya nilai identity }
$$

mengambarkan tingkat kemiripan antara protein target dan template (Benkert, et al., 2011). Hasil identifikasi menunjukkan bahwa template dengan PDB-ID 4f31.1.B adalah template yang digunakan dalam membangun struktur model, karena memiliki nilai identity tertinggi sebesar $94,43 \%$ dari 50 template yang teridentifikasi. Nilai identity yang diperoleh dari identifikasi template 
akan sangat membantu dalam memperoleh akurasi model yang sebenarnya.

\section{Komposisi protein CLOCK pada Patagioenas fasciata monilis}

Karakteristik suatu protein ditentukan oleh frekuensi asam amino dan jenis asam amino (Sunita, 2001). Komposisi protein meliputi sekumpulan asam amino yang saling berikatan, setiap komponen asam amino penyusun protein memiliki perbedaan pada rantai sampingnya (Gugus R). Hasil penelitian menunjukkan bahwa komposisi protein CLOCK pada Patagioenas fasciata monilis memiliki berat sebesar 96200,04 Daltons dan terdiri dari 852 asam amino, diantaranya adalah 42 aa Ala (4,93\%), 9 aa Cys (1,06\%), 34 aa Asp (3,99\%), 44 aa Glu $(5,16 \%), 35$ aa Phe $(4,11 \%), 37$ aa Gly $(4,34 \%), 34$ aa His $(3,99 \%), 35$ aa lle $(4,11 \%), 37$ aa Lys $(4,34 \%), 71$ aa Leu $(8,33 \%), 24$ aa Met $(2,82 \%), 37$ aa Asn $(4,34 \%), 46$ aa Pro $(5,40 \%), 107$ aa Gln $(12,56 \%), 35$ aa $\operatorname{Arg}(4,11), 90$ aa Ser $(10,56 \%), 66$ aa $\operatorname{Thr}(7,75 \%), 45$ aa $\mathrm{Val}$ $(5,28), 5$ aa $\operatorname{Trp}(0,59 \%)$ dan 19 aa Tyr $(2,23 \%)$.

Hasil analisis menunjukkan terdapat dua asam amino yang memiliki persentase jumlah paling besar yaitu asam amino glutamin dan serin. Besarnya nilai persentase komposisi kedua asam amino tersebut berhubungan dengan fungsi protein CLOCK. Aktivitas gen clock melibatkan protein CLOCK yang terdapat dalam sistem saraf pusat dan perifer sebagai salah satu faktor transkripsi sikardian clock (Takashi, 2017). Asam amino glutamin dan serin sangat mempengaruhi kerja dari sistem saraf, glutamin adalah asam amino non esensial yang berlimpah dan salah satu asam amino yang bisa secara langsung melewati sawar darah dalam saraf pusat (Arifin, 2009). Serin merupakan asam amino polar yang berperan penting didalam sistem saraf (Iriyanto, 2017) memiliki sifat hidrofilik yang berperan penting dalam menentukan struktur protein selama proses folding (Harti dan Soebiyanto, 2017).

\section{Struktur tiga dimensi protein CLOCK pada Patagioenas fasciata monilis}

Struktur protein telah menjadi teknik rutin untuk menghasilkan model 3D protein ketika struktur eksperimental tidak tersedia (Biasani, et al., 2014). Hasil penelitian menunjukkan bahwa struktur protein CLOCK pada Patagioenas fasciata monilis memiliki tiga daerah struktur beta-sheet dan lima daerah struktur alpha-helix (Gambar 1). Perbedaan struktur beta-sheet dan alpahelix dalam struktur protein dipengaruhi oleh rantai samping asam amino penyusunnya. Alpha-helix merupakan sebuah struktur yang berbentuk helikal atau biasa disebut spiral. Setiap kelompok karboksil dan kelompok amina saling terkait dengan ikatan hidrogen yang menyebabkan pembentukan spiral. Struktur beta sheet berbeda dengan struktur alpha-helix. Pada beta sheet rantai polipeptida terlipat secara terbalik pada setiap sisinya sehingga membentuk struktur seperti lembaran (Hafizh, 2016).

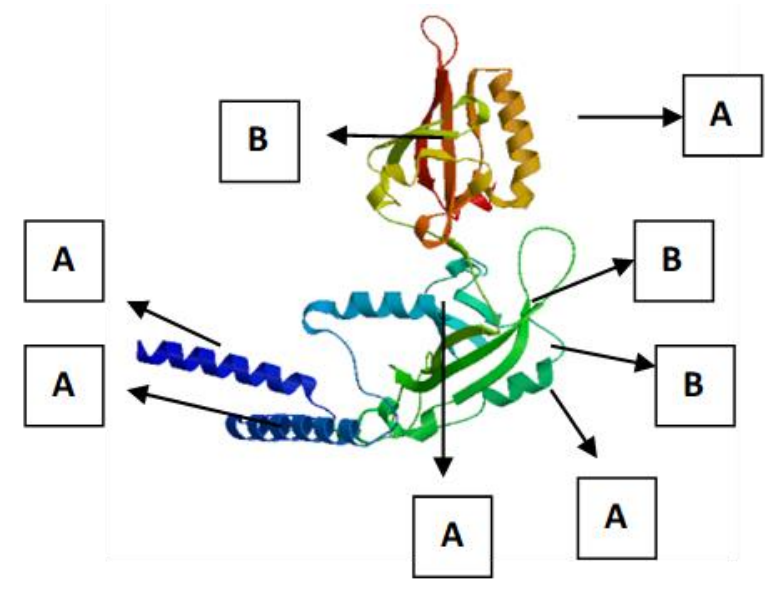

Gambar 1. Struktur Alpha-Helix (A) dan

$$
\text { Beta Sheet (B) }
$$

Struktur protein yang terbangun memiliki beberapa wilayah outliers. Daerah outliers menjadi dasar untuk mengetahui kualitas struktur protein. Kualitas struktur protein yang terbangun dapat dikategorikan baik apabila residu outliers hasil pemodelan homologi pada Swiss Model kurang dari 0,2\% (Yeni \& Tjahjono, 2017). Hasil penelitian menunjukkan adanya lima asam amino berada didaerah outliers, persentase jumlah asam amino didaerah outliers hanya berkisar $1,47 \%$ dan menggambarkan 
bahwa struktur yang diprediksi memiliki kualitas model yang baik. Kelima asam amino yang berada didaerah outliers diantaranya aa Asn B227, aa Ala B229, aa Asn B223, aa Arg B239 dan aa His B230 (Gambar 2).

$$
\text { Model yang diperoleh }
$$

menggambarkan adanya dua jenis asam amino tergolong dalam C-Beta Deviations diantaranya aa Asp B290 dan aa Glu B143 (Gambar 3). C-Beta Deviations menunjukkan adanya sejumlah asam amino yang tidak tepat sehingga menyebabkan struktur yang diprediksi tidak seutuhnya menunjukkan model yang sesungguhnya, akan tetapi struktur yang didapatkan masih termaksud kedalam kategori stabil berdasarkan persentase nilai template dan model, sesuai dengan tampilan result workspace protein target di swiss model (Suprianto, et al., 2020).

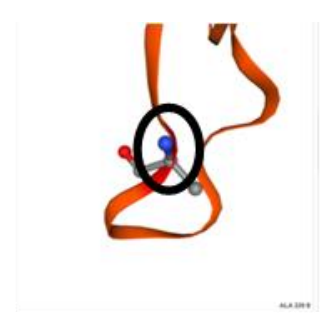

aa Asn B227

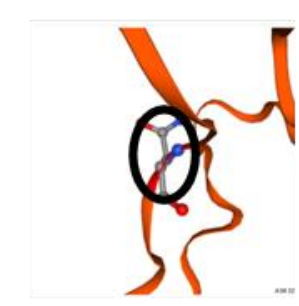

aa Ala B229

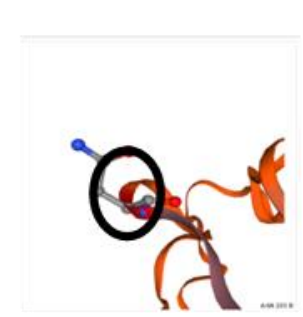

aa Asn B223

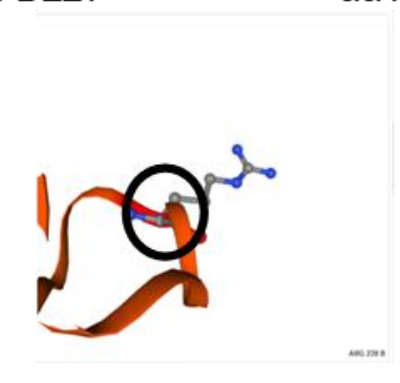

aa Arg B239

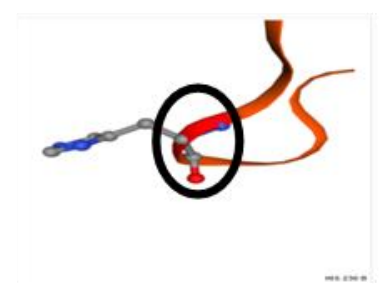

aa His $\mathrm{B} 230$

Gambar 2. Jenis Asam Amino diwilayah Outliers

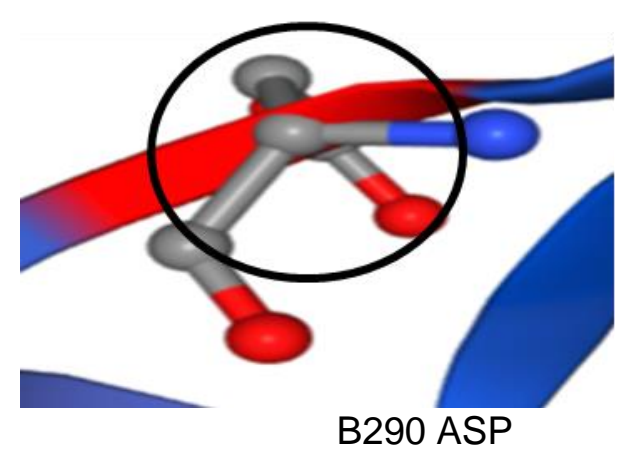

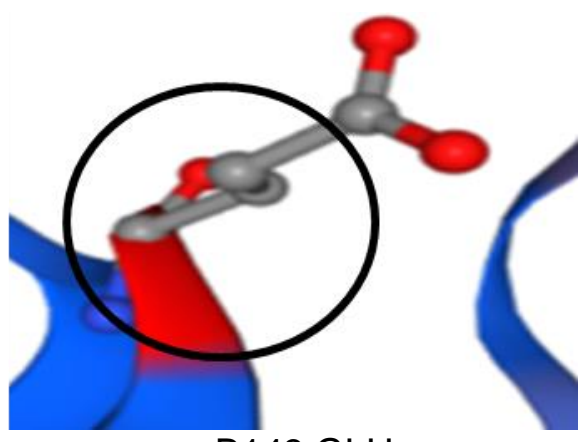

B143 GLU

Gambar 3. C-Beta Deviation 
Hasil penilaian struktur model menjelaskan terdapat sekitar 3929 sudut yang terbangun dan 34 diantaranya termaksud kategori sudut buruk (Bad Angles). Beberapa asam amino yang membentuk sudut buruk dapat dilihat pada Tabel 1.

Nilai Quality Model Energy Analysis (QMEAN) dan Global Model Quality Estimation (GMQE) digunakan untuk menggambarkan kualitas struktur protein yang telah diprediksi. Nilai QMEAN menggabungkan beberapa fungsi penilaian untuk memperkirakan kualitas model (Wijaya dan Hasanah, 2016). Nilai GMQE menandakan kecocokan antara residu struktur target dan template atau mencerminkan ekspektasi akurasi model. Hasil penilaian nilai QMEAN dan GMQE dapat dilihat pada Tabel 2. Hasil assessment menunjukkan bahwa struktur tiga dimensi protein yang diperoleh dari penelitian memiliki bentuk struktur yang baik, karena nilai QMEAN dan GMQE yang diperoleh masih berada pada batas normal (Tabel 2).
Tabel 1. Sudut Buruk Struktur Protein CLOCK pada Patagioenas fasciata monilis

\begin{tabular}{|c|c|}
\hline No & Sudut Buruk (Bad Angles) \\
\hline 1 & aa Pro B294 - aa Pro B295 \\
\hline 2 & aa Thr B139 - aa Pro B140 \\
\hline 3 & aa Val B225 - aa Pro B226 \\
\hline 4 & aa GIn B238 - aa Arg B239 \\
\hline 5 & aa Ala B293 - aa Pro B294 \\
\hline 6 & aa Asp B119 \\
\hline 7 & aa Asp B290 \\
\hline 8 & aa Gln B207 - aa Pro B208 \\
\hline 9 & aa Ile B158 - aa Pro B159 \\
\hline 10 & aa Asn B189 \\
\hline 11 & aa Phe B157 \\
\hline 12 & aa Asp B203 \\
\hline 13 & aa Ala B229 - aa His B230 \\
\hline 14 & aa His B163 \\
\hline 15 & aa Phe B219 \\
\hline 16 & aa His B144 \\
\hline 17 & aa His B230 \\
\hline 18 & aa His B241 \\
\hline 19 & aa His B280 \\
\hline 20 & aa His B373 \\
\hline 21 & aa Asp B178 \\
\hline 22 & aa His B325 \\
\hline 23 & aa His B291 \\
\hline 24 & aa His B314 \\
\hline 25 & aa His B84 \\
\hline 26 & aa Glu B271 - aa Pro B272 \\
\hline 27 & aa His B327 \\
\hline 28 & aa His B354 \\
\hline 29 & aa Ser B172 \\
\hline 30 & aa Ser B135 \\
\hline 31 & aa Asp B128 \\
\hline 32 & aa Glu B234 - aa Gly B235 \\
\hline 33 & aa Asp B203 - aa Pro B204 \\
\hline 34 & aa Ser B94 - aa Glu B95 \\
\hline
\end{tabular}

Tabel 2. Penilaian Struktur

\begin{tabular}{lcc}
\hline No & Assessment & Nilai \\
\hline 1. & Quality Model Energy Analisys (QMEAN) & $-1,69$ \\
2. & Global Model Quality Estimation (GMQE) & 0,31 \\
\hline
\end{tabular}




\section{SIMPULAN}

Hasil analisis penelitian menunjukkan bahwa protein CLOCK pada Patagioenas fasciata monilis dengan kode akses OPJ71137.1 (NCBI-ID) dan template 4f31.1.B (PDB-ID) memiliki struktur tiga dimensi protein yang nilai identitasnya mencapai 94,43 \%. Hasil struktur model menggambarkan terdapat 20 jenis asam amino dengan berat sebesar 96200,04 Daltons, memiliki tiga daerah struktur betasheet, lima daerah struktur alpha-helix, 1,47 $\%$ daerah outliers, dua residu C-Beta Deviations, 34 sudut buruk, nilai QMEAN 1,69 dan nilai GMQE 0,31. Hasil akhir penelitian dapat digunakan sebagai dasar untuk mempelajari perilaku Patagioenas fasciata monilis ditingkat molekuler.

\section{DAFTAR PUSTAKA}

Amelia. (2010). Penapisan In Silico beberapa Senyawa Bahan Alam Terhadap Aktivitas Protease HIV-1. Skripsi Sarjana Farmasi. Universitas Indonesia: Depok.

Arifin, A. (2009). Glutamine. Majalah Kedokteran Nusantara. 42(1).

Arnold, K., Bordoli, L., Kopp, J., \& Schwede T., (2006). The SWISS-MODEL Workspace: A Web-Based Environment For Protein Structure Homology Modeling. Bioinformatics. 22(2): 195-201.

Beale, A.D., Whitmore, D. \& Moran, D. (2016). Life in A Dark Biosphere: A Review of Circadian Physiology in Arrythmic Enviroments. J Comp Physiol B. 186(8).

Benkert, P., Biasini, M., \& Schwede, T. (2011). Toward The Estimation of The Absolute Quality of Individual Protein Structure Models. Bioinformatics. 27: 343-350.

Biasini, M., Bienert, S., Waterhouse, A., Arnold, K.., Studer G., Schmidt, T., Kiefer, F.,, Cassarino, T.G., Bertoni, M., Bordoli, L., and Schwede, T. (2014). SWISS-MODEL: Modelling Protein Tertiary and Quaternary Structure Msing Evolutionary Information. Nucleic Acids Research. 1-7.
Cassone, V.M. \& Westneat, D.F. (2012). The bird of time: cognition and the avian biological clock. Front Mol Neurosci. 5: 32.

Dor, R., Cooper, C.B., Lovette, I.J., Massoni, V., Bulit F., Liljesthrom M., Liljesthrom, D.W., (2011). Clock gene variation in Tachycineta swallows. Ecology and Evolution. 10(5) : 110-120.

Gekakis, N., David, S., Hubert, B.N., Fred, C.D., Lisa, D.W., Wilsbacer, D.P.K., Joseph, S.T., \& Charles, J.W. (1998). Role of The CLOCK Protein in The Mammalian Cicardian Mechanism. Research Articles. 280(5369): 9-1564.

Hafizh, A. (2016). Visualisasi Struktur Tersier Protein Berbasis Web Menggunakan Ribbon Drawing. Skripsi Sarjana Komputer. Institut Pertanian Bogor. Bogor.

Hardin, P.E. (2000). From Bilogical Clock to Biological Rhythms. Genome Biology. 1(4): 1023.1-1023.5.

Harti, A.S. \& Soebiyanto. (2017). Biokimia Kesehatan. Jakarta: Trans Info Media.

Hogan, C.M. (2008). Toyon (Heteromeles arbutifolia). Global Twitcher, ed. N. Stromberg: German.

Iriyanto, K. (2017). Biologi Molekuler. Edisi 1. Bandung: Alfabeta.

Johnsen, A., Fidler, A.E., Kuhn, S., Carter, K.L., Hoffman, A., Barr, I.R., Biard, C., Charmantier, A., Eens, M., Korsten, P., Siitari, H., Tomiuk, J., \& Kempenaers, B. (2007). Avian Clock Gene Polymorphism: Evidence for A Latitudinal Cline in Allele Frequencies. Molecular Ecology. 16: 4867-4880.

Nathaniel Rich (2014). The Mammoth Cometh. New York Times Magazine: USA.

Okamura, H. (2003). Intergration of Mammalian cicardian clock signal : from Molecul of Behavior. Journal of Endocrinol. 177: 3-6.

Panda, S., Hogenesch, J.B., \& Kay, S.A. (2002). Circadian Rhythms from Flies to Human. Nature. 417: 329-335.

Sunita A. (2001). Prinsip Dasar IImu Gizi. Jakarta: Gramedia Pustaka Utama.

Suprianto, Budiarsa, M., \& Dhafir, F. (2020). 3D Structure of VP1 Structural Protein on Enterovirus A71 Using Swiss- 
Model. BIOEDUSCIENCE: Jurnal Pendidikan Biologi Dan Sains, 4(1), 3747. https://doi.org/10.29405/j.bes/4137474353

Takashi, J.S. (2017). Transcriptional Architecture of The Mammalian Circadian Clock. Nat Rev Genet. 18(3): 164-179.

Wang, Z., Wu, Y., \& Xu, X.D. (2013). Intermolecular Recognition Revealed By The Complex Structure of Human CLOCK-BMAL1 Basic helix-loop-helix
Domain with E-Books DNA. Cell Research. 23: 213-224.

Wijaya H. \& F. Hasana. (2016). Prediksi struktur tiga dimensi protein allergen pangan dengan metode homologi menggunakan program SWISS MODEL. Biopropal Industri. 7(2): 8394.

Yeni \& Tjahjono, D.H. (2017). Homology Modeling Epitop Isocitrate Dehydrogenase Tipe 1 (R132h) 2 menggunakan Modeller, I-Tasser Dan (Ps) Untuk Vaksin Glioma. Farmasains. 4(1). 